\title{
Cristalización del jarabe de azúcar orgánica
}

Crystallization of the organic sugar cane syrup.

Patricio Alejandro Merino Córdova. ${ }^{1}$, Shakespeare Agustín Abarca Córdova. ${ }^{2}$, Byron Fabricio Estupiñan Cox. ${ }^{3} \&$ Daniel Eriel Izquierdo García. ${ }^{4}$

Recibido: 10-10-2018 / Revisado: 17-11-2018 /Aceptado: 04-12-2018/ Publicado: 05-012019

\begin{abstract}
.
DOI: https://doi.org/10.33262/cienciadigital.v3i1.275

The sustainability of sugar cane production by small farmers in Mauritius is seriously at risk due to several factors. These include: an increase in production costs and lower profitability caused by the fall in the international price of sugar. The situation is worsening, leading to widespread abandonment or conversion of lands, with social, economic and environmental consequences for local communities.
\end{abstract}

Keywords: Sugar cane, sugar cane land production environment

\section{Resumen}

La sostenibilidad de la producción de caña de azúcar por parte de pequeños agricultores en Mauricio está seriamente en riesgo debido a varios factores. Estos incluyen: un aumento en los costos de producción y una menor rentabilidad causada por la caída en el precio internacional del azúcar. La situación está empeorando, dando lugar a un abandono o conversión generalizada de tierras, con consecuencias sociales, económicas y ambientales para las comunidades locales.

Palabras clave: Caña de azúcar, Ambiente de producción de caña de azúcar.

\footnotetext{
${ }^{1}$ Universidad Técnica Luis Vargas Torres, Esmeraldas, Ecuador, patric_merino@hotmail.com

2 Universidad Técnica Luis Vargas Torres, Esmeraldas, Ecuador, shak63@ hotmail.es

3 Universidad Técnica Luis Vargas Torres, Esmeraldas, Ecuador, byrondj627@hotmail.com

${ }^{4}$ Universidad Técnica Luis Vargas Torres, Esmeraldas, Ecuador, jones_izquierdo23@hotmail.es
} 


\section{Introduction.}

Exponent of the sugarcane plant together with the beet, the sugarcane is a plant that, although typical of the tropics, enjoys worldwide fame for the manufacture of the sweetener par excellence, sugar. However, the use of sugarcane does not target only human food: in fact, particularly in recent years, the sugar plant is also used to obtain a biological propellant, the biofuel.

In botany, sugar cane is known as Saccharum officinarum, a plant that belongs to the Graminaceous family: the genus includes almost 40 different species and the most recognized commercial cultivars are hybrid complexes.

\section{Background}

Sugarcane is a perennial plant native to New Guinea: thanks to the Arabs, it was introduced first in Spain and then in Sicily, and then spread, immediately after the discovery of America, in the so-called West Indies.

Although its cultivation is still possible in some regions of southern Italy, it is not cultivated in our country; In Europe, sugar cane is widely grown only in the Iberian Peninsula, while in other parts of the world it is processed throughout Asia, America, Oceania and Africa.

In addition to sugarcane production, the plant is grown to obtain fresh salsa (guarapo) obtained by pressing and squeezing the culm; in addition, sugar cane is the matrix of fermented alcoholic beverages, liquors and alcohol.

\section{Botanical analysis}

Saccharum officinarum is a perennial tropical plant with a thick habit, which reaches an average of 4-5 meters in height, even if some species exceed 6 meters. The plant has a hard and angular rhizome, from which numerous woody stems interspersed with knots emerge. More than the drums, in the sugar cane we speak of canes, typically hollow, comparable to those of the bamboo: each plant is formed by a main "stem" branched in numerous aerial baskets.

The culm has a diameter of 3 to 5 centimeters, capable of reaching, or exceeding, even $10 \mathrm{~kg}$ of weight. The color, variable according to the species and the variety, can be yellow, violet, green or reddish.

The stems are covered with very long green leaves, lanceolate and embedded in knots with a pod that surrounds the culm. The flowers, very similar to those of oats and wheat, are collected in inflorescences called panicles, which can reach quite large dimensions $(90 \mathrm{~cm})$. The sugar is obtained from a syrupy fluid present inside the stem. 


\section{Reproduction and maturation.}

The reproduction of the plant is usually produced by cuttings: its transplant, which must take place in the middle of spring, requires an abundant amount of water so that, in the following months, a large amount of sugar can accumulate within the sap. It is correct to point out that, at the moment of harvesting for the subsequent extraction of sugar, the culm should not be torn, but cut, leaving the root unharmed: in this way, the stem can grow again and develop, the following year, it is ready for a new collection. In fact, sugarcane takes 12 months to reach full maturity; there are certainly no exceptions: in some areas, the plant takes 24 months to fully mature, while in another 6 months it is sufficient.

\section{Production of sugarcane in Ecuador}

"Sugarcane is considered one of the main production products in Latin America, for Ecuador its representation has its importance although to a lesser degree. The data of the Central Bank, informs us, that: the production of sugarcane contributes $1.4 \%$ to the national GDP and generates more than 30,000 direct and 80,000 indirect jobs, especially in the dry season of its harvest (July to December). Below are some interesting data on the production of this tropical plant "(Barcia, 2012).

\section{International Marketing}

The availability of international marketing of sugarcane is not abundant, but it is necessary to inform that: "sugar exports experienced growth both in volume of tons and in monetary value of the period of analysis under study, thus: 11,107.54 (Tm) were exported from July to December 2010 for a value of $\$ 7,750,350$, increasing the export level, since 12,156 (Tm) was

sold at an FOB value of $\$ 9,203,340$ in 2011. Our main international plaintiffs are: United States, since it was exported 11,098,810 (Tm) for a value of $\$ 7,735,870$; followed by Peru with $6.21(\mathrm{Tm})$ at a value of \$ 10,080 and Spain with $2.52(\mathrm{Tm})$ at a value of \$ 4,400 "(Banco Central del Ecuador, 2012 sf).

Graphic. One Sugar Exports (Quantities in tons)

\begin{tabular}{ccc}
\hline Year & Quantity in tons & Unit value \$ / tm \\
\hline 2005 & 13787 & 1690 \\
2006 & 14145 & 1813 \\
2007 & 12825 & 1988 \\
2008 & 14458 & 2250 \\
2009 & 9942 & 2217 \\
2010 & 11348 & 2467 \\
\hline
\end{tabular}


Source: Research Group.

Prepared by: Research group

The sugarcane producing countries of the world are located between $36.7^{\circ}$ north latitude and $31.0^{\circ}$ south of the equator, extending from tropical to subtropical zones.

\section{Botanical Classification}

Botanically, sugar cane has the following classification

\begin{tabular}{ll}
\hline \multicolumn{1}{c}{ Kingdom } & \multicolumn{1}{c}{ Plant } \\
\hline Division & Magnoliophyta \\
Class & Liliopsida \\
Subclass & Commelinidae \\
Order & Poales \\
Family & Poaceae \\
Subfamily & Panicoideae \\
Tribe & Andropogoneae \\
Gender & Saccharum \\
Species & S. officinarum L. \\
\hline
\end{tabular}

Source: Research Group.

Prepared by: Research group

\section{Phenological Stages of Cultivation}

The cultivation of sugarcane in its template cycle has a vegetative development of variable duration, given that it depends on the variety and the influence of the climate.

Graphic. Two Phonological stages of the cultivation of sugarcane

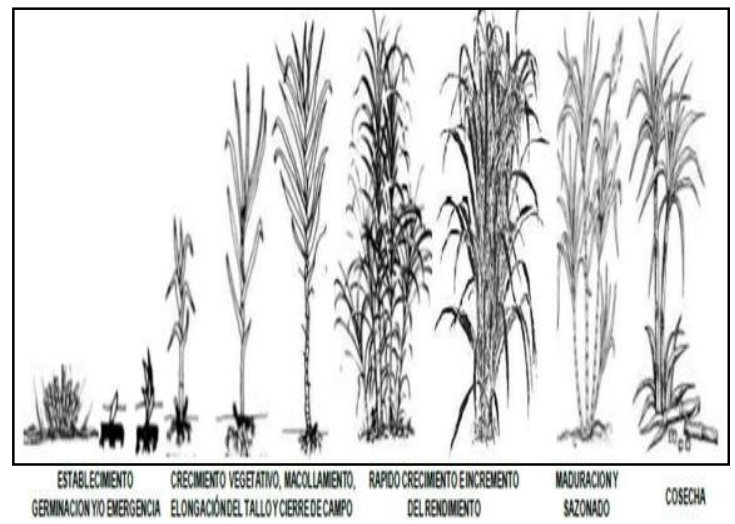


Source: Research Group.

Prepared by: Research group

Lightly browned organic cane sugar, obtained by evaporation and subsequent crystallization of cane syrup.

\section{Production}

\begin{tabular}{llc}
\hline INGREDIENTS & ADDITIVES & THE PRODUCT IS \\
\hline $\begin{array}{l}\text { Organic sugar } \\
\text { cane }\end{array}$ & Without & organic and not genetically \\
additives & modified or radiated \\
\hline
\end{tabular}

Organoleptic properties

\begin{tabular}{cccc}
\hline ODOR & COLOUR & TASTE & APPEARANCE \\
\hline Neutral & $\begin{array}{c}\text { ligeramente dorado max. } \\
800 \text { ICUMSA }\end{array}$ & Dolce & $\begin{array}{c}\text { Los cristales de azúcar, } \\
\text { tamaño: } 0,4 \text { a } 0,8 \mathrm{~mm}\end{array}$ \\
\hline
\end{tabular}

Packaging

\begin{tabular}{lcccc}
\hline $\begin{array}{l}\text { Net } \\
\text { weight }\end{array}$ & Type of packaging & $\begin{array}{c}\text { DIM } \\
\text { PACKAGE }\end{array}$ & $\begin{array}{c}\text { No } \\
\text { packages } \\
\text { for the layer }\end{array}$ & $\begin{array}{c}\text { No layer } \\
\text { per pallet }\end{array}$ \\
\hline \multirow{2}{*}{$25 \mathrm{~K}$} & $\begin{array}{c}\text { envelope in } \\
\text { multilayer paper, } \\
\text { PE coated }\end{array}$ & $70 \times 33 \times 18$ & 5 & 8 \\
\hline
\end{tabular}

The quality of conservation

\begin{tabular}{cc}
\hline STORAGE & MINIMUM \\
\hline Fresh, dry and dark & 3 years after harvest \\
\hline
\end{tabular}

The quality of preservation Nutritional information per 100 grams.

\begin{tabular}{lll}
\hline \multicolumn{1}{c}{ DETERMINATION } & \multicolumn{1}{c}{ RESULT } & \multicolumn{1}{c}{ UM } \\
\hline Energy value & 1674 & $\mathrm{Kcal} / \mathrm{Kj}$ \\
Grassi & 0.1 & \\
- of which saturated fats & 0 & \\
- of which mono unsaturated & - & -
\end{tabular}


- of which unsaturated pole

The carbohydrates

- of which sugars

- Glucose + Fructose

Protein

Sodium

vitamin A

Dietary fiber
$-$

99

89.9

$0,003-0,1 \quad \%$

0.5

0.05

$U I / R E$

0

$g$

\section{The Analytical Data}

\begin{tabular}{lll}
\hline \multicolumn{1}{c}{ DETERMINATION } & \multicolumn{1}{c}{ RESULT } & \multicolumn{1}{c}{ UM } \\
\hline Ash & $<0,07$ & $\%$ \\
Polarization & $>99,5$ & $\circ \mathrm{S}$ \\
external materials & $<10$ & $\mathrm{~N}^{\circ} / 100 \mathrm{~g}$ \\
Magnetic particles & máx. 0.1 & $\mathrm{mg} / \mathrm{kg}$ \\
Level of insoluble & $<10$ & \\
compounds & $<1,0$ & \\
sulfur dioxide &
\end{tabular}

Microbiological data

\begin{tabular}{lcc}
\hline \multicolumn{1}{c}{ DETERMINATION } & RESULT & UM \\
\hline Total Reproductivity bacteria & $<1,000$ & $u f c / g$ \\
Yeast & $<100$ & $u f c / g$ \\
Molds & $<100$ & $u f c / g$ \\
Coliforms & $<10$ & $u f c / g$ \\
Escherichia coli & 250 & $u f c / g$ \\
Salmonella & ausente & \\
Sulfate reducing bacteria & $<50$ & $u f c / g$ \\
Thermophilic aerobic bacteria & $<25$ & $u f c / g$ \\
Staphylococcus aureus & $<10$ & $u f c / g$ \\
Listeria monocytogenes & ausent & \\
\hline
\end{tabular}

Source: Research Group.

Prepared by: Research group 


\section{Conclusions.}

- Receive sugar cane, wash, cut into pieces, crushing, processing, extraction of sugar juice, heating, adjusting the $\mathrm{pH}$ by adding lime, sterilization $\left(105^{\circ} \mathrm{C}\right)$ of juice, clarification, sieving, filtering, pre-heating, evaporation, crystallization, centrifuge (separation of crystals from sugar molasses, drying, packaging.

- From sowing to harvest the crop can last from 14 and up to 17 months. In this period the sugarcane goes through four stages: germination and / or emergence, tillering, rapid growth and maturing. Meanwhile, the development of the socas (second cut of the cane) lasts from 11 to 13 months and there are three stages: sprouting and tillering, rapid growth and maturation. Next, each of these stages is described.

\section{Bibliographic References.}

Aitken-Christie J (1991) Automation En: Debergh, PC y Zimmerman , RJ (Eds) Micropropagation: Technology and Application, pp 363-388. Kluwer Academic Publishers, Dordrecht

Alvard D, Cote F y Teisson C (1993) Comparison of methods of liquid medium culture for banana micropropagation. Effests of temporary immersion. Plant Cell Tissue and Organ Culture 32: 55-60

CHEN C.P. James. Manual de Caña, Editorial Limusa. 1991 Aparicio Wilfredo,Herrera José

Escalant JV, Teisson C y Cote F (1994) Amplified somatic embryogenesis from male flowers of triploid banana and plantain cultivars (Musa spp.). In Vitro Cell.Dev. Biol Plant 30:181-186

Escalona MM (2000) Propagación de la piña (Annanas comosus (L) Merr) en Sistemas de inmersión temporal. Tesis presentada para optar por el grado a doctor en Ciencias Agrícolas. Ciego de Avila, pp.92

Etienne H y Berthouly M (2002) Temporary immersion systems in plant micropropagation. Plant Cell Tissue and Organ Culture 69: 215-231

Etienne H, Lartaud M, Ferriere N, Carron M, Berthouly M y Teisson C (1997) Improvement of somatic embryogenesis in Hevea brasiliensis (Mull. Arg) using the temporary immersion techniques. In vitro Cell Development Biol. 33: 81-87

Gómez KR (1996) Memorias del "I Curso Internacional de Semilla sintética o artificial". Capítulo 1. Generalidades sobre el cultivo in vitro: sus aplicaciones en especies tropicales de importancia económica. p 100-109 
Gómez KR, Gilliard T, Barranco LA (2000) Somatic embryogenesis in liquid medium.Maturation and enhancement of germination of the hybrid cultivar FHIA-18 (AAAB). InfoMusa. Vol.9 (1) 12-14

Jiménez GE (1995) Propagación in vitro de la caña de azúcar (Saccharum spp. híbrido). Tesis para optar por el grado científico de Doctor en Ciencias Agrícolas. Instituto de Biotecnología de las Plantas. Cuba .100 p.

M. Carmagnani, L'altro Occidente. L'America Latina dall'invasione European al novo millennio, Torino 2003.

Tellows P. Tecnología del Procesado de los Alimentos, Principios y Prácticas. Editorial Acribia, S.A. España 1994.

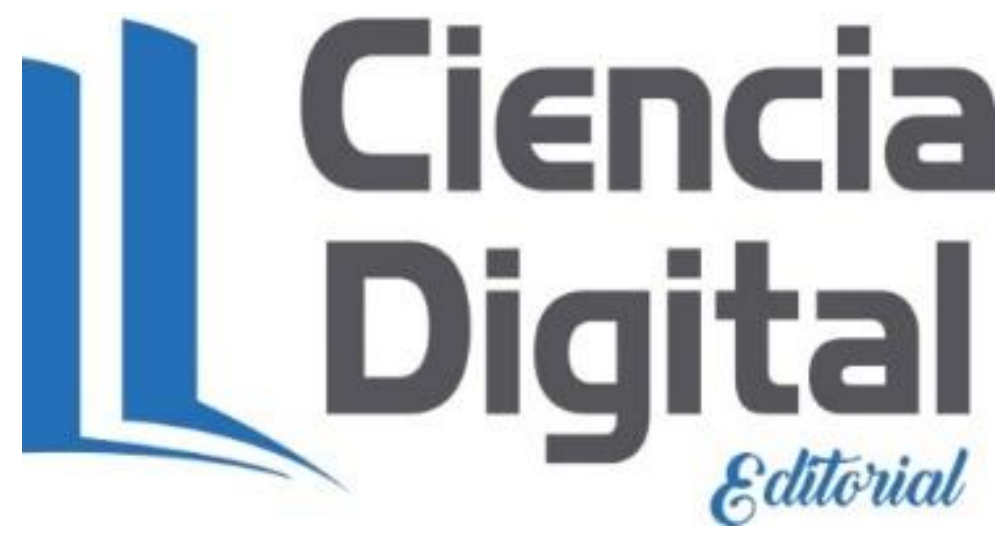




\section{Para citar el artículo indexado.}

Merino P., Abarca S., Estupiñan B. \& Izquierdo D. (2019). Cristalización del jarabe de azúcar orgánica. Revista electrónica Ciencia Digital 3(1), 128-136. Recuperado desde: http://cienciadigital.org/revistacienciadigital2/index.php/CienciaDigital/article/view/275/66 $\underline{1}$

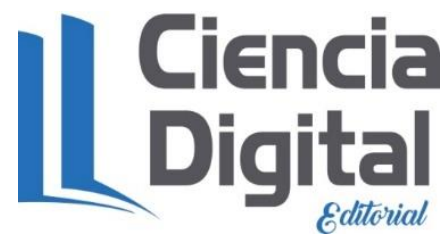

El artículo que se publica es de exclusiva responsabilidad de los autores y no necesariamente reflejan el pensamiento de la Revista Ciencia Digital.

El artículo queda en propiedad de la revista y, por tanto, su publicación parcial y/o total en otro medio tiene que ser autorizado por el director de la Revista Ciencia Digital.
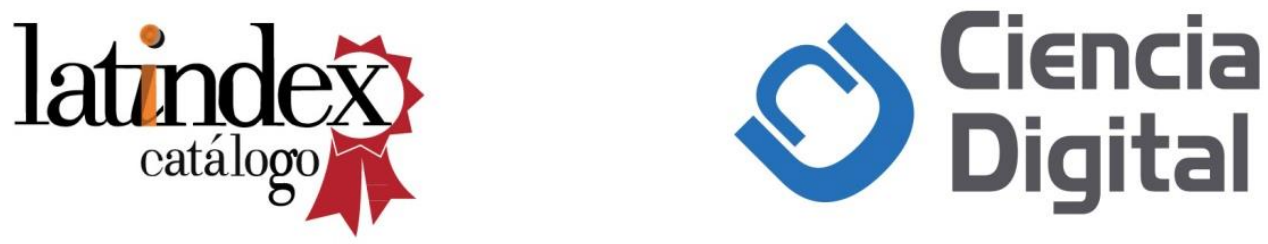